\title{
STUDI KONDISI LINGKUNGAN DAN PERSONAL HYGIENE PADA PENDERITA DIARE DI WILAYAH KERJA PUSKESMAS PEMARON KECAMATAN BREBES TAHUN 2017
}

\author{
Reni Nuraeni ${ }^{*}$, M.Choiroel Anwar ${ }^{* *}$ \\ Jurusan Kesehatan Lingkungan, Politeknik Kesehatan Kemenkes Semarang, \\ Jl.Raya Baturaden KM 12 Purwokerto, Indonesia
}

\begin{abstract}
Abstrak
Diare merupakan salah satu penyakit menular dapat di sebarkan oleh vektor pembawa bibit penyakit karena kondisi kesehatan lingkungan dan personal hygiene yang kurang baik. Dari data Dinas Kesehatan Kabupaten Berebes Kejadian diare di Kecamatan Brebes pada Tahun 2012 s/d 20164 Puskesmas yaitu Puskesmas Brebes, Kaligangsa, Kalimati, dan Pemaron, kasus Diare yang ditangani paling tinggi yaitu di Puskesmas Pemaron dengan jumlah penderita yang ditangani dari Tahun $2012 \mathrm{~s} / \mathrm{d}$ 2016 sebesar 26.252 jumlah penderita laki-laki dan perempuan yang ditangani.Tujuan dari KTI ini adalah Mengetahui kondisi sarana air bersih, kondisi sarana tempat pembuangan tinja rumah, Kondisi penyediaan dan penempatan sarana tempat sampah, dan mengetahui kondisi perilaku hygiene penderita penyakit diare di Wilayah Kerja Puskesmas Pemaron Kecamatan Brebes Tahun 2017.Jenis penelitian deskriptif yaitu menggambarkan keadaan yang sebenarnya dan membandingkan dengan teori yang ada.

Hasil penelitian yang dilakukan pada penderita diare di Wilayah Puskesmas Pemaron Kecamatan Brebes Kabupaten Brebes dapat diketahui (100\%) sumur gali yang tidak memenuhi syarat, Jamban leher angsa yang tidak memenuhi syarat (44,4\%) penerang tidak cukup, jamban cubluk tidak memenuhi syarat (0\%) terdiri dari lubang tanah yang tidak di gali, $(0 \%)$ tidak dibuat rumah jamban diatasnya,sarana sanitasi tidak memenuhi syarat (65\%) tidak Mempunyai tutup dan tidak mudah dibuka atau ditutup tanpa mengotori tangan, (100\%) volume tidak dapat menampung sampah yang dihasilkan oleh pemakai dalam waktu tertentu (3 hari), (0\%) tidak pernah menggunakan alat makan baik, (35\%)tidak pernah mencuci tangan dengan sabun sebelum makan, (25\%) tidak pernah mencuci tangan dengan sabun sehabis makan, (25\%)tidak pernah mencuci tangan dengan sabun sesudah buang air besar. (20\%) tidak pernah melakukan pembersihan dan pemotongan kuku, (65\%)tidak pernah meletakkan makanan dan minuman di tempat yang tertutup (45\%)tidak pernah memelihara sarana tempat pembuangan sampah, (90\%) kebiasaan tidak pernah memelihara tempat sumber air bersih

Kesimpulan yang dapat diambil dari penelitian ini adalah diare terjadi di karenakan kurang mengertinya masyarakat tentang PHBS (perilaku hidup bersih sehat) serta tingkat pendidikan yang rendah hal tersebut dapat menyebabkan angka kesakitan diare yang cukup tinggi di Wilayah Puskesmas Pemaron Kecamatan Brebes Kabupaten Brebes. Saran yang dapat diberikan adalah masyarakat harus rutin merawat sarana air bersih, sarana pembuangan tinja, sarana pembuangan sampah, dan berperilaku hidup bersih sehat seperti cuci tangan pakai sabun antiseptic sebelum dan sesudah makan, sesudah buang air besar, rutin melakukan pembersihan dan pemotongan kuku, meletakkan makanan dan minuman di tempat yang tertutup.
\end{abstract}

Kata kunci: diare;kesehatan lingkungan.

\begin{abstract}
The study environmental conditions and personal hygiene among dhiarrhea in working areas Puskesmas Pemaron Brebes year in 2017. Diarrhea is one of infectious disease can be spread by a disease vector seeds because the environmental health and personal hygiene a less well. District health offices berebes scene diarrhea in district brebes in brebes in $2012 s / d 2016$ in district brebes with 4
\end{abstract}


puskesmas are brebes, kaligangsa, kalimati, and pemaron, cases diarrhea handled the highest the puskesmas pemaron with there handled from year $2012 \mathrm{~s} / \mathrm{d} 2016$ a month 26.252 there men and women who handled. The purpose of kti this is know the state of clean water, the condition of the trash feces, the placement of the provision and the trash, and know the state of behavior hygiene of diarrhea sufferers in working areas puskesmas pemaron brebes year in 2017. The methodology used is the kind of research the results descriptive analyze using analysis table. The research was conducted in patients of diarrhea in the puskesmas pemaron in brebes district brebes it can be seen having clean water has been very good, defecate on privy is good, the provision and placement of trash is good enough, and personal hygiene is good enough A conclusion that may be drawn from research is diarrhea occurred due to less mengertinya people about phbs ( behaviors fresh healthy) and education levels this the cause of pain diarrhea spike in the puskesmas pemaron in brebes brebes district. Suggestions that can be given is the community must routine care for clean water, a stool disposal, means peembuangan trash, and behaving live cleanly healthy as hand washing with soap before and sesudsh eat, after defecate, routinely cleaning and cutting nails, put food and drink in an inclosed place.

Keywords:diarrhea; environmenthal health

\section{Pendahuluan}

Pembangunan kesehatan diselenggarakan dengan berdasarkan perikemanusiaan, keseimbangan, manfaat, pelindungan, penghormatan terhadap hak dan kewajiban, keadilan, gender dan nondiskriminatif dan norma-norma agama (UU No. 36/2009 Bab.II Pasal 2 tentang Kesehatan).

Menurut World Health Organization (WHO), penyakit diare adalah suatu penyakit yang ditandai dengan perubahan bentuk dan konsistensi tinja yang lembek sampai mencair dan bertambahnya frekuensi buang air besar yang lebih dari biasa, yaitu 3 kali atau lebih dalam sehari yang mungkin dapat disertai dengan muntah atau tinja yang berdarah. Penyakit ini paling sering dijumpai pada anak balita, terutama pada 3 tahun pertama kehidupan, dimana seorang anak bisa mengalami 1-3 episode diare berat (Simatupang: 2004).

Penyakit diare merupakan penyakit yang berbasis lingkungan. beberapa faktor yang berkaitan dengan kejadian diare yaitu tidak memadainya penyediaan air bersih, air tercemar oleh tinja, kekurangan sarana kebersihan (pembuangan tinja yang tidak higienis), kebersihan perorangan dan lingkungan yang jelek, penyiapan makanan kurang matang dan penyimpanan makanan masak pada suhu kamar yang tidak semestinya (Sander, 2005).

Banyak faktor yang secara langsung maupun tidak langsung menjadi pendorong terjadinya diare yaitu faktor agent, penjamu, lingkungan dan perilaku. Faktor lingkungan merupakan faktor yang paling dominan yaitu sarana penyediaan air bersih dan pembuangan tinja, kedua faktor berinteraksi bersama dengan perilaku manusia. Apabila faktor lingkungan tidak sehat karena tercemar kuman diare serta terakumulasi dengan perilaku manusia yang tidak sehat, maka penularan diare dengan mudah dapat terjadi (Zubir et al, 2006).

Hingga saat ini penyakit Diare masih merupakan masalah kesehatan masyarakat, hal ini dapat dilihat dengan meningkatnya angka kesakitan diare dari tahun ke tahun. Di dunia, sebanyak 6 juta anak meninggal setiap tahun karena diare, sebagian kematian tersebut terjadi di negara berkembang. berdasarkan WHO, kematian karena diare di Indonesia sudah menurun tajam. Begitu pula berdasarkan survey rumah tanngga, kematian karena diare diperkirakan menurun. Walaupun angka kematian diare menurun, angka kesakitan karena diare tetap tinggi terutama di negara berkembang. (Kemenkes RI,2011)

Di negara berkembang seperti Indonesia sendiri penyakit diare masih merupakan masalah kesehatan masyarakat, karena morbiditas dan mortalitasnya yang masih tinggi. Tahun $2000 \mathrm{~s} / \mathrm{d} 2010$ terlihat kecenderungan insiden naik. Pada tahun 2000 IR penyakit Diare 301/ 1000 penduduk, tahun 2003 naik menjadi $374 / 1000$ penduduk, tahun 2006 naik menjadi $423 / 1000$ penduduk dan tahun 2010 menjadi 411/1000 penduduk. Kejadian Luar Biasa (KLB) diare juga masih sering terjadi, dengan CFR yang masih tinggi. (Kemenkes RI,2011)

Menurut data dari Dinas Kesehatan Provinsi Jawa Tengah, rumah merupakan salah satu kebutuhan dasar manusia yang berfungsi sebagai tempat tinggal atau hunian dan sarana pembinaan keluarga. Rumah haruslah sehat dan nyaman agar penghuninya dapat berkarya untuk meningkatkan produktivitas. Konstruksi rumah dan lingkungan yang tidak memenuhi syarat kesehatan merupakan faktor risiko penularan berbagai jenis penyakit khususnya penyakit berbasis lingkungan seperti Demam Berdarah Dengue, Malaria, Flu Burung, TBC, ISPA, Diare dan lain-lain. Rumah yang memenuhi syarat kesehatan di Jawa Tengah tahun 2015 sebesar 75,37 persen.

Kabupaten Brebes merupakan salah satu dari 35 Kabupaten atau kota di Provinsi Jawa Tengah. Berdasarkan data dari Dinas Kesehatan Kabupaten Berebes Kejadian diare di Kabupaten Brebes Kecamatan 
Brebes pada tahun 2012 s/d 2016 di kecamatan Brebes dengan 4 puskesmas yaitu puskesmas Brebes, Kaligangsa, Kalimati, dan Pemaron, kasus Diare yang ditangani paling tinggi yaitu di puskesmas Pemaron dengan jumlah penderita yang ditangani dari tahun 2012 s/d 2016 yaitu sebesar 26.252 jumlah penderita laki-laki

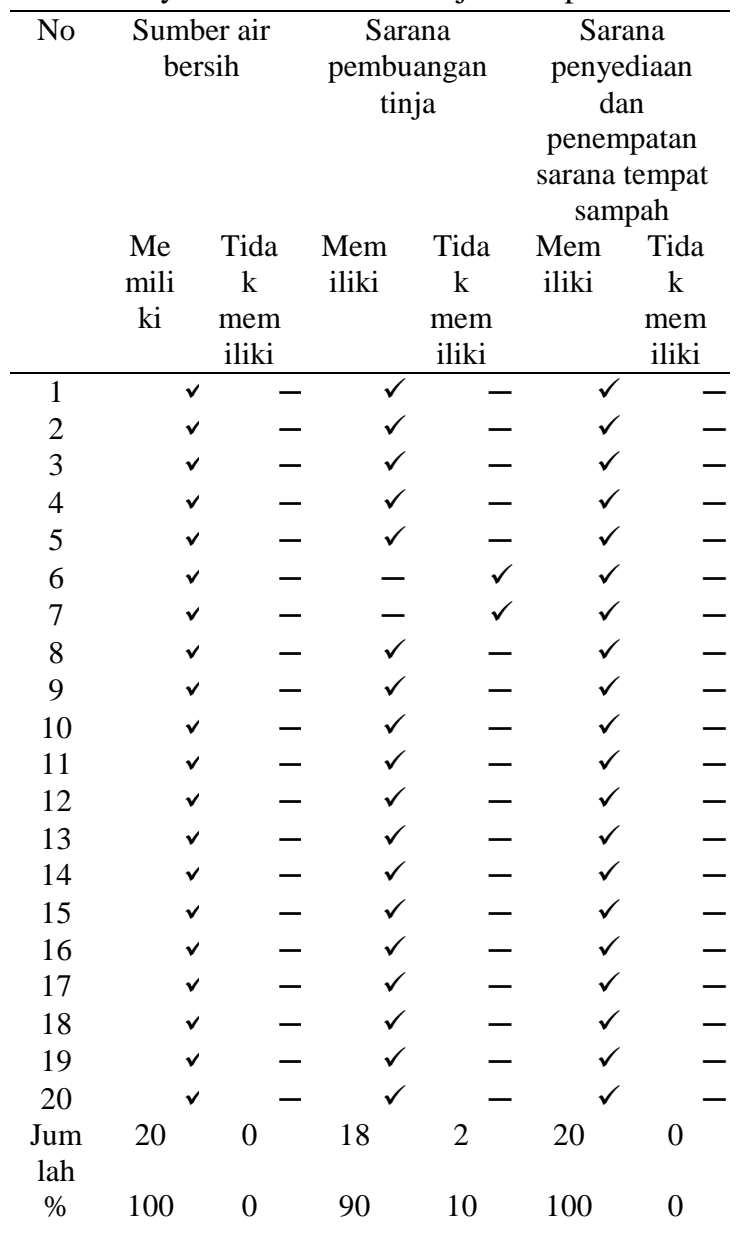

dan perempuan yang ditangani.

Kejadian diare berhubungan dengan kondisi sarana lingkungan yang meliputi: sumber air bersih tidak memenuhi syarat, pembuangan tinja yang tidak saniter, penyediaan dan penempatan tempat sampah yang tidak saniter, perilaku tidak higienis.

Berdasarkan latar belakang diatas penulis tertarik untuk melakukan penelitian dengan judul "Studi Kondisi Lingkungan dan Personal Hygiene pada Penderita Diare di Wilayah Kerja Puskesmas Pemaron Kecamatan Brebes Tahun 2017'.

\section{Bahan dan Metode}

Jenis penelitian yang digunakan adalah jenis penelitian deskriptif yaitu menggambarkan kondisi lingkungan dan personal hygiene lingkungan terhadap rumah penderita diare di Wilayah Kerja Puskesmas Pemaron Kecamatan Brebes.

Cara pengukuran data dilakukan dengan cara wawancara, observasi dan dokumentasi.

\section{Hasil dan Pembahasan}

a. Kepemilikan Sarana Sanitasi dan Personal Hygiene Penderita Diare

Tabel 1.Distribusi Kepemilikan Sarana Sumber Air Bersih, Pembuangan dan Penampungan Tinja, Penyediaan Dan Penempatan Sarana Tempat Sampah, Personal Hygiene Responden Penderita DiareDi Wilayah Kerja Puskesmas Pemaron Kecamatan Brebes Tahun 2016

$100 \%$ kepemilikan sarana sumber air bersih, $90 \%$

kepemilikan sarana pembuangan tinja, 100\%

kepemilikan penyediaan dan penempatan sarana tempat sampah.

b. Kondisi sarana air bersih

Tabel 2.Distribusi Responden Penderita Diare BerdasarkanJenis Sarana air Bersih Di Wilayah Kerja Puskesmas Pemaron Kecamatan Brebes Tahun 2016

\begin{tabular}{clcc}
\hline No. & \multicolumn{1}{c}{ Variabel } & Jumlah & $\%$ \\
\hline 1. & $\begin{array}{l}\text { Responden yang } \\
\text { menggunakan air } \\
\text { bersih dari } \\
\text { sumur gali } \\
\text { (SGL) }\end{array}$ & 12 & $60 \%$ \\
2. & $\begin{array}{l}\text { Responden yang } \\
\text { menggunakan air } \\
\text { bersih dari } \\
\text { perpipaan } \\
\text { Jumlah }\end{array}$ & 8 & $40 \%$ \\
& 20 & 100
\end{tabular}

$\overline{60 \% \text { menggunakan SGL, dan } 40 \% \text { menggunakan }}$ perpipaan.

Tabel 3.DistribusiI Sarana Air Bersih Jenis SGL Yang Memenuhi SyaratDi Wilayah Kerja Puskesmas PemaronKecamatan Brebes Tahun 2016

\begin{tabular}{|c|c|c|c|c|c|c|c|}
\hline \multirow[t]{2}{*}{$\mathrm{N}$} & \multirow[t]{2}{*}{ Variabel } & \multicolumn{2}{|c|}{ MS } & \multicolumn{2}{|c|}{ TMS } & \multirow{2}{*}{$\begin{array}{c}\mathrm{J} \\
\mathrm{ml}\end{array}$} & \multirow[t]{2}{*}{$\%$} \\
\hline & & Jml & $\%$ & Jml & $\%$ & & \\
\hline 1 & 2 & 3 & 4 & 5 & 6 & 7 & 8 \\
\hline 1 & SUMUR GALI & 0 & 0 & 12 & $\begin{array}{l}1 \\
0 \\
0\end{array}$ & 12 & 100 \\
\hline & $\begin{array}{lr}\text { a.Lokasi } & \text { jarak } \\
\text { minimal } & 15 \text { meter } \\
\text { terletak lebih tinggi } \\
\text { dari } & \text { sumber } \\
\text { pencemaran } & \text { seperti } \\
\text { kakus, } & \text { kandang } \\
\text { ternak, } & \text { tempat } \\
\text { sampah } & \end{array}$ & 12 & $\begin{array}{l}1 \\
0 \\
0\end{array}$ & 0 & 0 & 12 & 100 \\
\hline & $\begin{array}{l}\text { b. Dinding sumur di } \\
\text { lapisi dengan batu } \\
\text { yang disemen. } \\
\text { Pelapisan dinding } \\
\text { sumur paling tidak } \\
\text { sedalam } 6 \text { meter } \\
\text { dari permukaan }\end{array}$ & 12 & $\begin{array}{l}1 \\
0 \\
0\end{array}$ & 0 & 0 & 12 & 100 \\
\hline
\end{tabular}




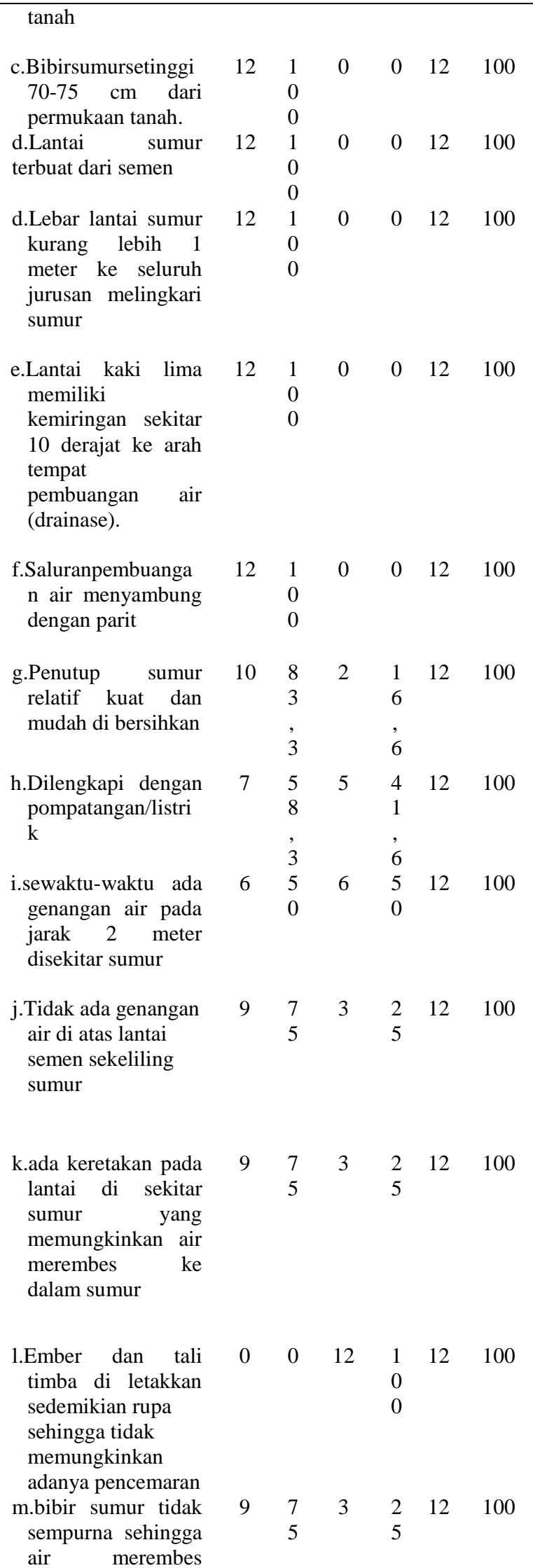

\begin{tabular}{lllllll}
\hline kedalam sumur & & & & & & \\
n.dinding sumur & 8 & 6 & 4 & 3 & 12 & 100 \\
sedalam 3 m dari & & 6 & & 3 & & \\
atas permukaan & & 6 & &, & & \\
tanah di plester & & 6 & & 3 & & \\
$\quad$ rapat atau tidak & & & & & & \\
$\quad$ sempurna & 8 & 4 & 0 & 0 & 8 & 40 \\
PERPIPAAN & 8 & & & & \\
\hline
\end{tabular}

12 variabel (100\%) lokasi jarak minimal $15 \mathrm{~m}$ lebih tinggi dari sumber pencemaran, 12 variabel (100\%) dinding sumur yang dilapisi batu yang di semen, 12 variabel $(100 \%)$ bibir sumur setinggi $70-75 \mathrm{~cm}$ dari permukaan tanah, 12 variabel $(100 \%)$ lantai sumur terbuat dari semen, $100 \%$ lebar lantai sumur kurang lebih $1 \mathrm{~m}$ ke seluruh jurusan melingkari sumur, 12 variabel $(100 \%)$ lantai kaki lima memiliki kemiringan sekitar 10 derajat kearah tempat pembuangan, 12 variabel (100\%) saluran pembuangan menyabung dengan parit, dan yang tidak memenuhi syarat yaitu pada 12 variabel $(100 \%)$ ember dan tali timba di letakkan sedemikian rupa sehingga tidak memungkinkan adanya pencemaran.

c. Kondisi Sarana Pembuangan dan Penampungan Tinja

Tabel 4.Distribusi Jenis Sarana Pembuangan Dan Penampungan Tinja Responden Penderita Diare

Di Wilayah Kerja Puskesmas Pemaron

Kecamatan Brebes

Tahun 2016

\begin{tabular}{cccc}
\hline No & Variable & Jumlah & $\%$ \\
\hline 1. & $\begin{array}{l}\text { Jamban } \\
\text { cubluk }\end{array}$ & 2 & 10 \\
2. & $\begin{array}{l}\text { Jamban } \\
\text { leher } \\
\text { angsa } \\
\text { Jumlah }\end{array}$ & 18 & 90 \\
& 20 & 100 \\
\hline
\end{tabular}

90\% penderita diare membuang tinja di jamban leher angsa, dan $10 \%$ penderita membuang tinja di jamban cubluk.

Tabel 5.Distribusi Sarana Pembuangan Dan Penampungan Tnja

Jenis Jamban Leher Angsa Dan Jamban Cubluk Yang Memenuhi Syarat Di Wilayah Kerja Puskesmas Pemaron

Kecamatan Brebes Tahun 2016

\begin{tabular}{clcccccc}
\hline $\mathrm{N}$ & Variabel & \multicolumn{2}{c}{ MS } & \multicolumn{2}{c}{ TMS } & $\mathrm{Jm}$ & $\%$ \\
$\mathrm{o}$ & & $\mathrm{Jm}$ & $\%$ & $\mathrm{Jm}$ & $\%$ & 1 & \\
& & 1 & & 1 & & & \\
1 & & 2 & 4 & 5 & 6 & 7 & 8 \\
\hline 1. & JAMBAN & 0 & 0 & 2 & 100 & 2 & 10 \\
& $\begin{array}{l}\text { CUBLUK } \\
\text { a. Terdiri dari } \\
\quad\end{array}$ & 0 & 0 & 2 & 100 & 2 & 10 \\
& $\begin{array}{l}\text { lubang dari } \\
\text { tanah yang di }\end{array}$ & & & & & & 0 \\
\hline
\end{tabular}




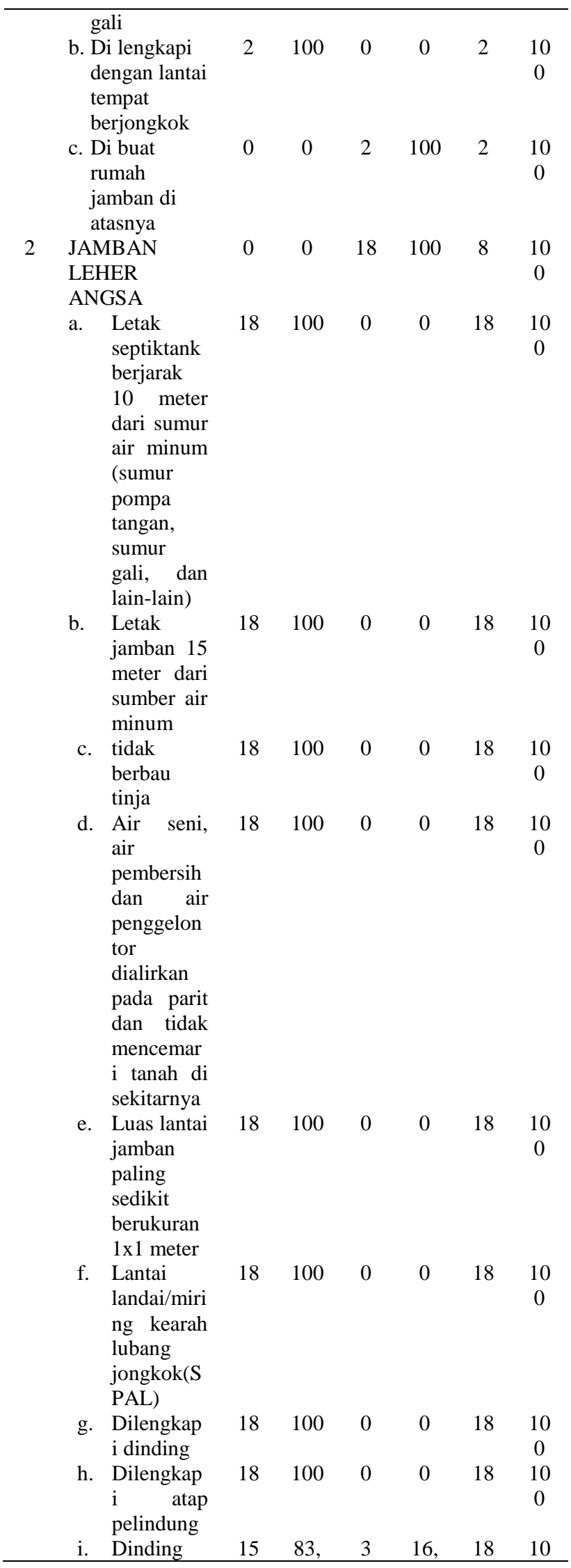

\begin{tabular}{|c|c|c|c|c|c|c|c|}
\hline & $\begin{array}{l}\text { kedap air } \\
\text { berwarna } \\
\text { terang }\end{array}$ & & 3 & & 6 & & 0 \\
\hline $\mathrm{j}$. & $\begin{array}{l}\text { Peneranga } \\
\text { n cukup }\end{array}$ & 10 & $\begin{array}{c}55 \\
5\end{array}$ & 8 & $\begin{array}{c}44 \\
4\end{array}$ & 18 & $\begin{array}{c}10 \\
0\end{array}$ \\
\hline & $\begin{array}{l}\text { Lantaikeda } \\
\text { p air }\end{array}$ & 18 & 100 & 0 & 0 & 18 & $\begin{array}{c}10 \\
0\end{array}$ \\
\hline & $\begin{array}{l}\text { Luas } \\
\text { ruangan } \\
\text { cukup }\end{array}$ & 13 & $\begin{array}{c}72 \\
2\end{array}$ & 5 & $\begin{array}{c}27 \\
7\end{array}$ & 18 & $\begin{array}{c}10 \\
0\end{array}$ \\
\hline & Tersediaair & 18 & 100 & 0 & 0 & 18 & $\begin{array}{c}10 \\
0\end{array}$ \\
\hline & $\begin{array}{l}\text { Tersedia alat } \\
\text { pembersih }\end{array}$ & 18 & 100 & 0 & 0 & 18 & $\begin{array}{c}10 \\
0 \\
\end{array}$ \\
\hline
\end{tabular}

2 variabel (100\%) di lengkapi dengan lantai berjongkok, dan yang tidak memenuhi syarat yaitu 0 variabel $(0 \%)$ terdiri dari lubang tanah yang di gali, dan 0 variabel $(0 \%)$ dibuat rumah jamban diatasnya, dan jenis jamban leher angsa variabel yang memenuhi syarat dapat diketahui 18 variabel (100\%) jamban yang memiliki letak penampungan kotoran Jenis tanah berkapur atau tanah liat kurang lebih berjarak 10 meter dari sumur air minum (sumur pompa tangan, sumur gali, dan lain-lain), 18 variabel (100\%) 15m letak jamban di atas sumber air minum pada tanah yang miring, 18 variabel $(100 \%)$.

Tidak berbau tinja, 18 variabel (100\%) Air seni,air pembesih,dan air penggelontor tidak mencemari tanah, 18 variabel ( $100 \%)$ memiliki luas lantai jamban paling sedikit berukuran 1x1 meter, 100\% Lantai landai/miring kearah lubang jongkok (SPAL), 18 variabel (100\%) Dilengkapi dinding, 18 variabel (100\%) Dilengkapi atap pelindung, dan 18 variabel (100\%) Lantai kedap air, dan yang belum memenuhi syarat 8 variabel $(44,4 \%)$ penerang tidak cukup.

d. Kondisi Sarana Pembuangan dan Penempatan Sampah

Tabel 6.Distribusi Sarana Penyediaan Dan Penempatan Tempat Sampah Yang Memenuhi Syarat Kontruksi, Volume, Lokasi

Di Wilayah Kerja Puskesmas Pemaron Kecamatan Brebes Tahun 2016

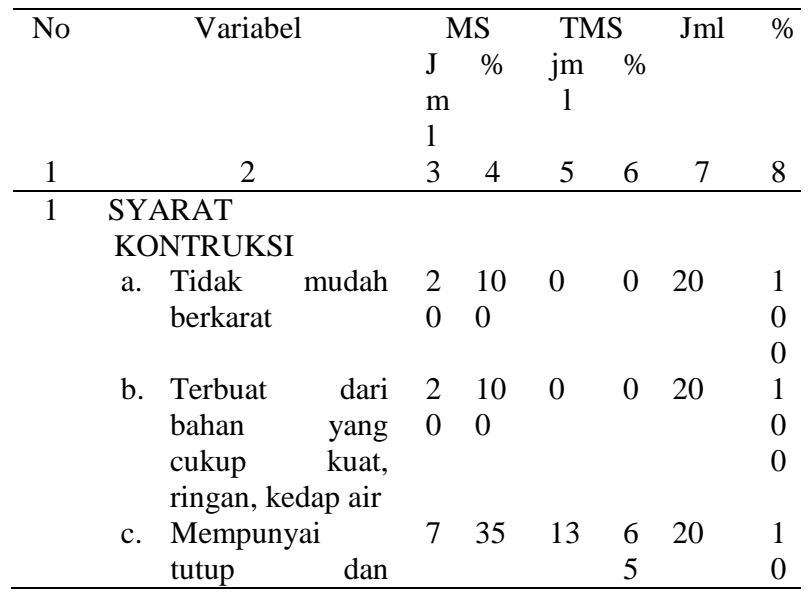




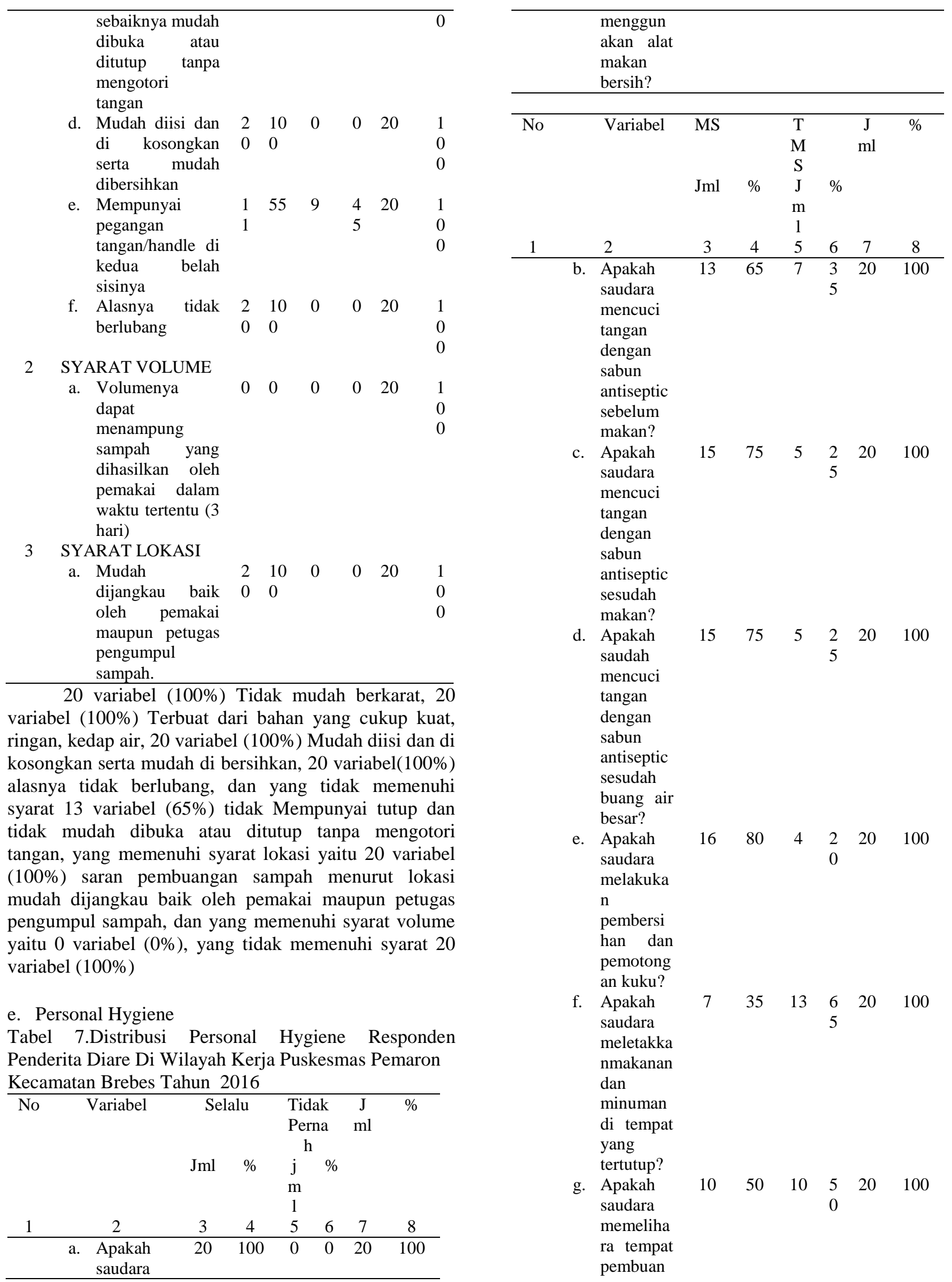


gan tinja?

h. Apakah

saudara

memlihar

a tempat

pembuan

gan

sampah?

i. Apakah

saudara

memeliha

ra tempat

sumber

airbersih?

20 variabel $(100 \%)$ responden selalu

menggunakan alat masak bersih, 0 variabel $(0 \%)$ responden tidak pernah menggunakan alat masak bersih

Tiga belas variabel (65\%) kebiasaan selalu mencuci tangan dengan sabun sebelum makan, dan 7 variabel $(35 \%)$ kebiasaan tidak pernah mencuci tangan dengan sabun antiseptic sebelum makan.

Lima belas variabel (75\%) kebiasaan selalu mencuci tangan sesudah makan, dan 5 variabel (25\%) kebiasaan tidak pernah mencuci tangan dengan sabun antiseptic sehabis makan.

Lima belas variabel (75\%) kebiasaan selalu mencuci tangan dengan sabun sesudah buang air besar, dan 5 variabel (25\%) kebiasaan tidak mencuci tangandengan sabun antiseptic sesudah buang air besar.

Enam belas variabel (80\%) kebiasaan selalu melakukan pembersihan dan pemotongan kuku, dan 4 variabel $(20 \%)$ kebiasaan tidak pernah melakukan pembersihan dan pemotongan kuku.

Tujuh variabel (35\%) kebiasaan selalu meletakkan makanan dan minuman di tempat yang tertutup, dan 13 variabel (65\%) kebiasaan tidak pernah meletakkan makanan dan minuman di tempat yang tertutup

Sepuluh variabel $(50 \%)$ kebiasaan selalu memelihara tempat pembuangan tinja, dan10 variabel (50\%) kebiasaan tidak pernah memelihara tempat pembuangan tinja.

Sebelas variabel (55\%) kebiasaan selalu memelihara sarana tempat pembuangan sampah, 9 variabel $(45 \%)$ kebiasaan tidak pernah memelihara sarana tempat

Dua variabel (10\%) kebiasaan selalu memelihara tempat sumber air bersih, dan 18 variabel $(90 \%)$ kebiasaan tidak pernah memelihara tempat sumber air bersih.

\section{Kesimpulan}

a. Kepemilikan sarana air bersih 20 orang (100\%), kondisi sarana air bersih yang menggunakan sumur gali yang memenuhi syarat 0 unit $(0 \%)$, tidak memenuhi syarat 12 unit $(60 \%)$ dan perpipaan memenuhi syarat 8 unit (40\%), tida memenuhi syarat 0 unit $(0 \%)$.

b. Kepemilikan sarana tempat pembuangan tinja 20 orang (100\%), kondisi sarana tempat pembuangan tinja jenis jamban cubluk yang memenuhi syarat 0 unit $(0 \%)$, tidak memenuhi syarat 2 unit (10\%), dan jenis jamban leher angsa yang memenuhi syarat 0 unit $(0 \%)$, yang tidak memenuhi syarat 18 unit $(90 \%)$.

c. Kepemilikan penyediaan dan penempatan sarana tempat sampah 20 orang $(100 \%)$ kondisi sarana penyediaan dan penempatan tempat sampah yang memenuhi syarat kontruksi 0 unit $(0 \%)$, dan yang tidak memenuhi syarat kontruksi 20 unit (100\%), yang memenuhi syarat volume 0 unit $(0 \%)$, dan yang tidak memenuhi syarat volume 20 unit (100\%), yang memenuhi syarat kontruksi 20 unit (100\%) dan yang tidak memenuhi syarat lokasi 0 unit $(0 \%)$.

d. Berdasarkan penelitian personal hygiene penderita diare di Wilayah Kerja Puskesmas Pemaron dari 20 rumah responden penderita diketahui 20 orang $(100 \%)$ selalu menggunakan alat makan bersih baik, $0(0 \%)$ tidak pernah, 13 orang $(65 \%)$ kebiasaan selalu mencuci tangan dengan sabun sebelum makan, dan 7 orang $(35 \%)$ tidak pernah, 15 orang $(75 \%)$ kebiasaan selalu mencuci tangan dengan sabun sesudah makan, dan 5 orang $(25 \%)$ tidak pernah, 15 orang $(75 \%)$ kebiasaan selalu mencuci tangan dengan sabun sesudah buang air besar,dan 5 orang (25\%) tidak pernah, 16 orang (80\%) kebiasaan selalu melakukan pembersihan dan pemotongan kuku, dan 4 orang (20\%) tidak pernah melakukan pembersihan dan pemotongan kuku, 7 orang $(35 \%)$ kebiasaan selalu meletakkan makanan dan minuman di tempat yang tertutup, dan 13 orang $(65 \%)$ tidak pernah, 10 orang $(50 \%)$ kebiasaan selalu memelihara tempat pembuangan tinja, dan 10 orang $(50 \%)$ tidak pernah, 11 orang $(55 \%)$ kebiasaan selalu memelihara sarana tempat pembuangan sampah, dan 9 orang (45\%) tidak pernah, 2 orang $(10 \%)$ kebiasaan selalu memelihara tempat sumber air bersih, dan 18 orang $(90 \%)$ tidak pernah.

\section{Ucapan Terimakasih}

Peneliti mengucapkan banyak terima kasih kepada pihak pemilik industri biogas limbah cair di Desa Kalikidang yang telah memberikan izin tempat penelitian dan membantu dalam pelaksanaan penelitian, serta seluruh pihak yang telah membantu terselesaikannya penelitian ini. 


\section{Daftar Pustaka}

Arikunto, Suharsimi, 1988, Prosedur Penelitian Suatu Pendekatan Praktek, Jakarta: Rineka Cipta

Chandra, Budiman, 2006,Pengantar Kesehatan Lingkungan, Jakarta: Penerbit Buku Kedokteran EGC

Departemen Kesehatan RI Direktorat Jendral PPM \& PLP,1998, Pedoman Perilaku Hygienis. Jakarta: Depkes

diakses pada tanggal 16 januari 2017 pukul 10:00 WIB

Fitriani, Nur Kholif, 2009, Studi Aspek Kesehatan Lingkungan Rumah Penderita Diare di Wilayah Kerja Puskesmas Baturraden II Kecamatan Baturraden Kabupaten Banyumas, Purwokerto: Politeknik Kesehatan Kementerian Kesehatan Semarang Jurusan Kesehatan Lingkungan

Handayani, Dian Esti, 2011, Studi Keadaan Sarana Sanitasi Rumah Penderita Diare Di Desa Pesdurungan Kecamatan Taman Kabupaten Pemalang, Purwokerto: Politeknik Kesehatan Kementerian Kesehatan Semarang Jurusan Kesehatan Lingkungan.

http://digilib.esaunggul.ac.id/public/UEU-Journal-4522Intan.pdf diakses pada tanggal 17 januari 2017 pada pukul 21:45 WIB

http://digilib.unila.ac.id/2281/10/BAB\%20II.pdf diakses pada tanggal 17 januari 2017 pada pukul 21:31 WIB

http://dinkesjatengprov.go.id/v2015/dokumen/profil201 5/Profil_2015_fix.pdf diakses pada tanggal 18 januari 2017 pada pukul 15:00 WIB

http://ejournal.poltekkespontianak.ac.id/index.php/JVK/article/download/ 64/40 diakses pada selasa 11 juli 2017 pukul 10:53 WIB

http://fourseasonnews.blogspot.co.id/2013/05/definisidiare-menurut-para-ahli.html diakses pada tanggal 15 januari 2017 pada pukul 16:30 WIB

http://nasuwakesaceh.ac.id/.gudang/file/pdf/jurnal-pdfjTIoJre4BEwVEY2d.pdf diakses pada selasa 11 juli 2017 pukul 10:51 WIB

http://repository.usu.ac.id/bistream/handle/123456789/3 4137/chapter\%20II.pdf?sequence $=4$ diakses pada selasa 11 juli 2017 pukul 10:56

http://repository.usu.ac.id/bitstream/123456789/23245/4 /Chapter\%20II.pdf diakses pada tanggal 15 Januari 2017 pada pukul 14:04 WIB http://www.depkes.go.id/download.php?file=download/. pusdatin/buletin-diare.pdf diakses pada tanggal 18 januari 2017 pada pukul 15:00 WIB

http://www.depkes.go.id/resources/download/profil/.PR OFIL_KAB_KOTA_2014/3329_jateng_Kab_Bre bes_2014.pdf diakses pada tanggal 18 januari 2017 pada pukul 15:00 WIB

. diakeses pada tanggal 27 Juli 2017 pada pukul 16:35 WIB

Notoatmodjo, Soekidjo, Metodologi Penelitian Kesehatan, Jakarta:Rineka Cipta

Peraturan Menteri Kesehatan Republik Indonesia Tahun 2015 tentang Penyelenggaraan Pelayanan Kesehatan Lingkungan di Puskesmas

Sarudji, Didik, 2010, Kesehatan Lingkungan, Bandung: CV.Karya Putra Darwati

http://www.ejournal.uui.ac.id/jurnal/Zulfitri-ooxjurnal_zulfitri_oke.pdf diakses pada selasa 11 juli 2017 pada pukul 10:46 WIB

http://www.indonesian-publichealth.com/syarat-jambankeluarga/ diakses pada tanggal 17 januari 2017 pada pukul 21:30 WIB

Kementerian Republik Indonesia tahun 2011 tentang Pengendalian Diare di Indonesia

Maqassary, Al Ardi, 2013, Pengertian Diare, dikutip dari laman : http://www.ejurnal.com/2013/04/pengertiandiare.htmlSuparlan, 2012, Pengantar Hygiene Sanitasi Tempat-Tempat Umum Wisata dan Usaha untuk Umum

Undang-Undang Republik Indonesia Nomor 36 Tahun 2009 tentang Kesehatan

Zulkoni, Akhsin, 2010, Parasitologi, Yogyakarta: Nuha Medika 